\title{
Pengaruh Harga Produk dan Kualitas Pelayanan terhadap Kepuasan Pelanggan Kitchen Outlet Berbasis Online di Wilayah Tangerang Selatan
}

\author{
${ }^{1}$ Haudi*, ${ }^{2}$ Hadion Wijoyo, ${ }^{3}$ Denok Sunarsi \\ ${ }^{1}$ Sekolah Tinggi Agama Buddha Dharma Widya \\ ${ }^{2}$ STMIK Dharmapala.Riau \\ ${ }^{3}$ Universitas Pamulang
}

\begin{abstract}
Alamat Surat
Email: ${ }^{1}$ haudi.stabdw@gmail.com, ${ }^{2}$ hadion.wijoyo@lecturer.stmikdharmapalariau.ac.id, 3denoksunarsi@unpam.ac.id
\end{abstract}

Article History:

Received: 10-Nopember-2020; Received in Revised: 25-Nopember-2020; Accepted: 30-Nopember-2020

\section{ABSTRAK}

Penelitian ini bertujuan untuk mengetahui pengaruh harga produk dan kualitas pelayanan terhadap kepuasan pelanggan Kitchen outlet berbasis online di Wilayah Tangerang Selatan. Metode yang digunakan adalah explanatory research dengan teknik analisis menggunakan analisis statistik dengan pengujian regresi, korelasi, determinasi dan uji hipotesis. Hasil penelitian ini harga produk berpengaruh signifikan terhadap kepuasan pelanggan sebesar 40,4\%, uji hipotesis diperoleh t hitung $>\mathrm{t}$ tabel atau $(8,061>1,985)$. Kualitas pelayanan berpengaruh signifikan terhadap kepuasan pelanggan sebesar 50,8\%, uji hipotesis diperoleh $t$ hitung $>t$ tabel atau $(9,951>1,985)$. Harga produk dan kualitas pelayanan secara simultan berpengaruh signifikan terhadap kepuasan pelanggan dengan persamaan regresi $\mathrm{Y}=9,390+0,281 \mathrm{X} 1+0,490 \mathrm{X} 2$ dan kontribusi pengaruh sebesar $56,2 \%$, uji hipotesis diperoleh $\mathrm{F}$ hitung $>\mathrm{F}$ tabel atau $(60,957>2,770)$.

Kata kunci: Harga Produk, Kualitas Pelayanan, Kepuasan Pelanggan

ABSTRACT

This study aims to determine product prices and service quality on customer satisfaction in onlinebased Kitchen outlets in Wilayah, South Tangerang. The method used is explanatory research with analysis techniques using statistical analysis with regression testing, correlation, determination, and hypothesis testing. The results of this study that the product price has a significant effect on customer satisfaction by $40.4 \%$, hypothesis testing obtained $t$ count $>$ t table or $(8,061>1,985)$. Service quality significantly affects customer satisfaction by 50.8\%; hypothesis testing obtained $t$ count $>t$ table or (9.951> 1.985). Product price and service quality simultaneously significantly affect customer satisfaction with the regression equation $Y=9.390+0.281 X 1+0.490 X 2$, and the contribution of the effect is $56.2 \%$, the hypothesis test obtained $F$ count $>F$ table or $(60,957>2,770)$.

Keywords: Product Prices, Service Quality, Customer Satisfaction

\section{PENDAHULUAN}

Didalam dunia era gelobalisai yang super cangih sekarang masyarakat lebih mudah dalam memenuhi kebutuhan kehidupan mereka sekarang. Berbelanja secara online tentu menjadi kesenangan tersendiri bagi pembeli. Hanya dengan terhubung ke internet, kita bisa langsung memilih barang apayang cocok dan akan kita beli. Ketika belanja secara online, kita akan menjumpai berbagai macam sistem yang diberlakukan oleh penjual. Ada yang memberlakukan sistem tanya jawab, yaitu 
kita bebas menanyakan seputar produk yang kita beli langsung kepada admin, ada juga yang dengan langsung membeli tanpa harus bertanya kepada admin. Suatu Online Shop harus memliki kecepatan dan ketelitian dalam berjualan didunia maya, karena jika online shop tersebut lambat membalas chat atau pertanyaan pertanyaan yang diajukan coustumer akan bepindah keonline shop lain, untuk membuat coutumer lebih nyaman ketika berbelanja online dan tanpa harus terlalu banyak bertanya online shop tersebut harus menjelaskan detail produk mereka secara terperinci dan lampirkan juga foto produk aslinya. Online shop tersebut seharusnya tidak boleh menggunakan foto prdouk yg bukan property online shop itu sendiri karena jika produk yang coustumer terima berbeda dengan produk yang mereka lihat, dan itu akan mengurangi kepuasan pelanggan saat berbelanja dionline shop tersebut. Bukan hanya online shop saja kita juga dapat berbelanja online di e-commerce dan marketplace yang hanya menggunakan internet.

Yang membedakan antara Online shop dan Marketplase ialah dari item belanja dan system penjualannya juga sedikit berbeda, jika dionline shop pembeli dapat melakukan pembayaran langsung kepada penjual melalui rekening pribadi sedangkan marketplace pembayarannya hanya bisa dilakukuan dengan metode yang telah diteteapkan online Website tersebut. Marketplase iyalah seperti, Tokopedia, Bukalapak, Shopee, Lazada, Belibeli.com dan masih banyak yang lain. Sistem belanja e-commerce hampir sama dengan marketplace, yaitu pembeli tinggal memilih barang yang diinginkan pada sebuah website, kemudian mengklik tombol "beli" dan melakukan transfer sejumlah harga yang tercantum. Bedanya adalah pada e-commerce, barang ataupun produk yang dijual berasal dari website itu sendiri. Ia tidak membuka lahan atau tempat bagi para penjual lain untuk menjajakan produk mereka. Tidak ada tawar menawar dan harga yang diberikan adalah harga pas. Contoh ecommerce misalnya zalora.com, berrybenka.com, dan lainnya. Harga adalah nilai dari suatu barang atau jasa yang diukur dengan jumlah uang dimana berdasarkan nilai tersebut seseorang atau penguasa bersedia melepaskan barang dan jasa yang dimiliki kepada pihak lain". Willian J. Stanton (1991) menyatakan, "Harga adalah nilai yang disebutkan dalam rupiah dan sen atau medium moneter lainnya sebagai alat tukar". Berikut ini merupakan table Data penjualan:

Tabel Data Penjualan Kitchen Outlet 2016-2019

\begin{tabular}{cccc}
\hline Tahun & Target & Realisasi & Pencapaian \\
\hline 2016 & Rp 500.000.000 & Rp 400.000.000 & $80 \%$ \\
2017 & Rp 100.000.000 & Rp 830.000.000 & $83 \%$ \\
2018 & Rp 110.000.000 & Rp 120.000.000 & $120 \%$ \\
2019 & Rp 120.000.000 & Rp 960.000.000 & $80 \%$
\end{tabular}

Dari tabel penjualan tersebut dapat dilihat bahwa penjualan toko kitchen outlet pada tahun 2016, 2017 dan 2019 tidak tercapainya target. Pelayanan merupakan suatu proses keseluruhan dari pembentukan citra perusahaan, baik melalui media berita, membentuk budaya perusahaan secara internal, maupun melakukan komunikasi tentang pandangan perusahaan kepada para pemimpin pemerintahan serta publik lainnya yang berkepentingan. Menurut Moenir dalam bukunya Manajemen Pelayanan Umum Di Indonesia, mengatakan bahwa: Pelayanan adalah proses pemenuhan kebutuhan melelui aktivitas orang lain secara langsung. (Moenir, 1992). Penekanan terhadap definisi pelayanan diatas adalah pelayanan yang diberikan menyangkut segala usaha yang dilakukan oleh seseorang dalam rangka mencapai tujuan guna untuk mendapatkan kepuasan dalan hal pemenuhan kebutuhan.

Kepuasan adalah perasaan senang atau kecewa seseorang yang muncul setelah membandingkan antara persepsi atau kesan terhadap kinerja atau hasil suatu produk dan harapan-harapannya. Dengan demikiankepuasan merupakan fungsi dari persepsi atau kesan atas kinerja dan harapan.Jika kinerja berada dibawah harapan maka pelanggan tidak puas. Jika kinerja memenuhi harapan maka pelanggan akan puas. Jika kinerja melebihi harapan maka pelanggan merasa sangat puas atau senang. Kunci untuk menghasikan kesetian pelanggan adalah memberikan nilai pelanggan yang akan meyimpulkan bahwa kepuasan konsumen merupakan suatu tanggapan perilaku konsumen berupa evaluasi purna 
beli terhadap suatu barang atau jasa yang dirasakannya (kinerja produk) dibandingkan dengan harapan konsumen. Kepuasan konsumen ini sangat tergantung pada persepsi dan harapan konsumen itu sendiri.

\subsection{Kajian Pustaka Harga Produk}

Penetapan harga menurut Alma (2015) adalah keputusan mengenai harga- harga yang akan di ikuti dalam jangka waktu tertentu. Harga yang di tetapkan lebih tinggi daripada nilai yang diterima, perusahaan tersebut akan kehilangan kemungkinan untuk memetik laba, jika harganya ternyata terlalu rendah daripada nilai yang diterima, perusahaan tersebut tidak akan berhasil menuai kemungkinan memperoleh laba.

\section{Kualitas Pelayanan}

Kotler dalam Alma (2019), mengungkapkan bahwa kualitas pelayanan adalah suatu cara kerja perusahaan yang berusaha mengadakan perbaikan mutu secara terus-menerus terhadap proses, produk dan service yang dihasilkan perusahaan. Sedangkan menurut Tjiptono (2017), kualitas pelayanan merupakan upaya pemenuhan kebutuhan dan keinginan konsumen serta ketepatan penyampaiannya dalam mengimbangi harapan konsumen. Kualitas pelayanan dapat diukur dengan lima dimensi sesuai dengan urutan derajat kepentingan relatifnya (Tjiptono, 2017), yaitu keandalan, jamin, bukti fisik, empati an dan daya tanggap.

\section{Kepuasan Pelanggan}

Kotler dan Keller (2017) mengungkapkan kepuasan adalah perasaan senang atau kecewa seseorang yang berasal dari perbandingan antara kesannya terhadap kinerja (atau hasil) suatu produk dan harapan harapannyaLovelock dan Wright (2013) menyatakan bahwa, kepuasan adalah keadaan emosional, reaksi pascapembelian mereka, dapat berupa kemarahan, ketidakpuasan, kejengkelan, netralitas, kegembiraan dan kesenangan. Kepuasan dipengaruhi oleh perbandingan layanan yang dipahami dengan pelayanan yang diharapkan, dan sebagai reaksi emosional jangka pendek pelanggan terhadap kinerja pelayanan tertentu. Indikator untuk mengukur kepuasan pelanggan.

\section{METODE}

Jenis penelitian yang dipakai adalah asosiatif, dimana tujuannya adalah untuk mengetahui pengaruh antara variabel bebas terhadap variabel terikat baik parsial maupun simultan. Populasi dalam penelitian ini berjumlah 98 responden Kitchen outlet berbasis online di Wialayah Tangerang Selatan. Sampel dalam penelitian ini berjumlah 98 responden. Dalam menganalisis data digunakan uji instrumen, uji asumsi klasik, regresi, koefisien determinasi dan uji hipotesis

\section{HASIL DAN PEMBAHASAN}

\subsection{Hasil}

\section{Analisis Deskriptif}

Pada pengujian ini digunakan untuk mengetahui skor minimum dan maksimum, mean score dan standar deviasi dari masing-masing variabel. Adapun hasilnya sebagai berikut:

Tabel Hasil Analisis Descriptive Statistics

\begin{tabular}{lrrrrr}
\multicolumn{7}{c}{ Descriptive Statistics } \\
\hline Harga produk (X1) & 98 & 32 & 48 & 38.27 & Std. Deviation \\
Kualitas pelayanan (X2) & 98 & 30 & 47 & 38.61 & 3.921 \\
Kepuasan pelanggan (Y) & 98 & 31 & 47 & 39.08 & 3.847 \\
Valid N (listwise) & 98 & & & & 3.637
\end{tabular}


Harga produk diperoleh varians minimum sebesar 32 dan varians maximum 48 dengan mean score sebesar 38,27 dengan standar deviasi 3,921. Kualitas pelayanan diperoleh varians minimum sebesar 30 dan varians maximum 47 dengan mean score sebesar 38,61 dengan standar deviasi 3,847. Kepuasan pelanggan diperoleh varians minimum sebesar 31 dan varians maximum 47 dengan mean score sebesar 39,08 dengan standar deviasi 3,637.

\section{Analisis Verifikatif.}

Pada analisis ini dimaksudkan untuk mengetahui pengaruh variabel independen terhadap variabel dependen. Adapun hasil pengujian sebagai berikut:

\section{Analisis Regresi Linier Berganda}

Uji regresi ini dimaksudkan untuk mengetahui perubahan variabel dependen jika variabel independen mengalami perubahan. Adapun hasil pengujiannya sebagai berikut:

\section{Tabel Hasil Pengujian Regresi Linier Berganda}

\begin{tabular}{|c|c|c|c|c|c|}
\hline \multicolumn{6}{|c|}{ Coefficients $^{a}$} \\
\hline \multirow[b]{2}{*}{ Model } & \multicolumn{2}{|c|}{$\begin{array}{l}\text { Unstandardized } \\
\text { Coefficients }\end{array}$} & $\begin{array}{l}\text { Standardized } \\
\text { Coefficients }\end{array}$ & \multirow[b]{2}{*}{$\mathrm{t}$} & \multirow[b]{2}{*}{ Sig. } \\
\hline & $\mathrm{B}$ & Std. Error & Beta & & \\
\hline $1 \quad$ (Constant) & 9.390 & 2.712 & & 3.463 & .001 \\
\hline Harga produk (X1) & .281 & .082 & .303 & 3.431 & .001 \\
\hline Kualitas pelayanan (X2) & .490 & .084 & .518 & 5.861 & .000 \\
\hline a. Dependent Variable: Kepu & langgan & & & & \\
\hline
\end{tabular}

Berdasarkan hasil pengujian pada tabel di atas, diperoleh persamaan regresi $\mathrm{Y}=9,390+$ 0,281X1 + 0,490X2. Dari persamaan tersebut dijelaskan sebagai berikut:

a. Konstanta sebesar 9,390 diartikan jika harga produk dan kualitas pelayanan tidak ada, maka telah terdapat nilai kepuasan pelanggan sebesar 9,390 point.

b. Koefisien regresi harga produk sebesar 0,281, angka ini positif artinya setiap ada peningkatan harga produk sebesar 0,281 maka kepuasan pelanggan juga akan mengalami peningkatan sebesar 0,281 point.

c. Koefisien regresi kualitas pelayanan sebesar 0,490, angka ini positif artinya setiap ada peningkatan kualitas pelayanan sebesar 0,490 maka kepuasan pelanggan juga akan mengalami peningkatan sebesar 0,490 point.

\section{Analisis Koefisien Korelasi}

Analisis koefisien korelasi dimaksudkan untuk mengetahui tingkt kekuatan hubungan dari variabel independen terhadap variabel dependen baik secara parsial maupun simultan. Adapun hasil pengujian sebagai berikut:

Tabel Hasil Pengujian Koefisien Korelasi Harga Produk Terhadap Kepuasan Pelanggan.

\begin{tabular}{|c|c|c|c|}
\hline \multicolumn{4}{|c|}{ Correlations $^{\text {b }}$} \\
\hline & & Harga produk (X1) & Kepuasan pelanggan (Y) \\
\hline \multirow[t]{2}{*}{ Harga produk (X1) } & Pearson Correlation & 1 & $.635^{* *}$ \\
\hline & Sig. (2-tailed) & & .000 \\
\hline \multirow[t]{2}{*}{ Kepuasan pelanggan (Y) } & Pearson Correlation & $.635^{* *}$ & 1 \\
\hline & Sig. (2-tailed) & .000 & \\
\hline
\end{tabular}


Berdasarkan hasil pengujian diperoleh nilai korelasi sebesar 0,635 artinya harga produk memiliki hubungan yang kuat terhadap kepuasan pelanggan.

Tabel Hasil Pengujian Koefisien Korelasi Kualitas Pelayanan Terhadap Kepuasan Pelanggan.

Correlations $^{\mathrm{b}}$

\begin{tabular}{llrr}
\hline & & Kualitas pelayanan & \\
& & $(\mathrm{X} 2)$ & \multicolumn{1}{c}{ Kepuasan pelanggan (Y) } \\
\hline Kualitas pelayanan (X2) & Pearson Correlation & & $.713^{* *}$ \\
& Sig. (2-tailed) & & .000 \\
Kepuasan pelanggan (Y) & Pearson Correlation & $.713^{* *}$ & 1 \\
& Sig. (2-tailed) & .000 &
\end{tabular}

Berdasarkan hasil pengujian diperoleh nilai korelasi sebesar 0,713 artinya kualitas pelayanan memiliki hubungan yang kuat terhadap kepuasan pelanggan.

Tabel Hasil Pengujian Koefisien Korelasi Harga Produk dan Kualitas pelayanan secara simultan Terhadap Kepuasan pelanggan.

\section{Model Summary}

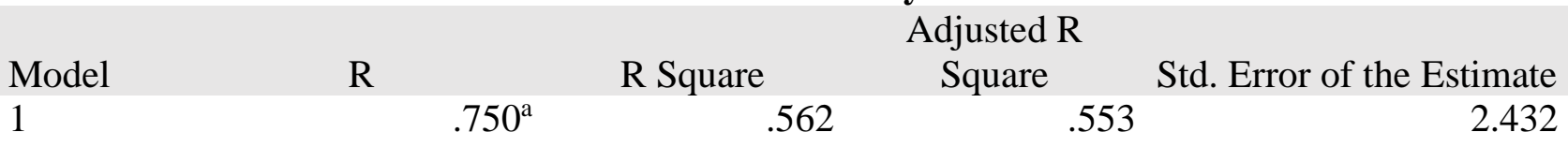

a. Predictors: (Constant), Kualitas pelayanan (X2), Harga produk (X1)

Berdasarkan hasil pengujian diperoleh nilai korelasi sebesar 0,750 artinya harga produk dan kualitas pelayanan secara simultan memiliki hubungan yang kuat terhadap kepuasan pelanggan.

\section{Analisis Koefisien Determinasi}

Analisis koefisien determinasi dimaksudkan untuk mengetahui besarnya persentase pengaruh dari variabel independen terhadap variabel dependen baik secara parsial maupun simultan. Adapun hasil pengujian sebagai berikut:

Tabel Hasil Pengujian Koefisien Determinasi Harga produk Terhadap Kepuasan pelanggan.

\section{Model Summary}

\begin{tabular}{|c|c|c|c|c|}
\hline Model & $\mathrm{R}$ & R Square & $\begin{array}{l}\text { Adjusted R } \\
\text { Square }\end{array}$ & $\begin{array}{l}\text { Std. Error of the } \\
\text { Estimate }\end{array}$ \\
\hline 1 & $.635^{\mathrm{a}}$ & .404 & .397 & 2.823 \\
\hline
\end{tabular}

a. Predictors: (Constant), Harga produk (X1)

Berdasarkan hasil pengujian diperoleh nilai determinasi sebesar 0,404 artinya harga produk memiliki kontribusi pengaruh sebesar 40,4\% terhadap kepuasan pelanggan.

Tabel 7. Hasil Pengujian Koefisien Determinasi Kualitas Pelayanan Terhadap Kepuasan Pelanggan.

Model Summary

\begin{tabular}{llrrrr}
\hline & & \multicolumn{2}{c}{} & Adjusted R & \multicolumn{2}{c}{$\begin{array}{c}\text { Std. Error of the } \\
\text { Estimate }\end{array}$} \\
\hline 1 & $\mathrm{R}$ & & R Square & Square & \multicolumn{2}{c}{ Estimat } \\
\hline & $.713^{\mathrm{a}}$ & .508 & .503 & 2.565
\end{tabular}

a. Predictors: (Constant), Kualitas pelayanan (X2) 
Berdasarkan hasil pengujian diperoleh nilai determinasi sebesar 0,508 artinya kualitas pelayanan memiliki kontribusi pengaruh sebesar 50,8\% terhadap kepuasan pelanggan.

Tabel Hasil Pengujian Koefisien Determinasi Harga produk dan Kualitas pelayanan Terhadap Kepuasan pelanggan.

\section{Model Summary}

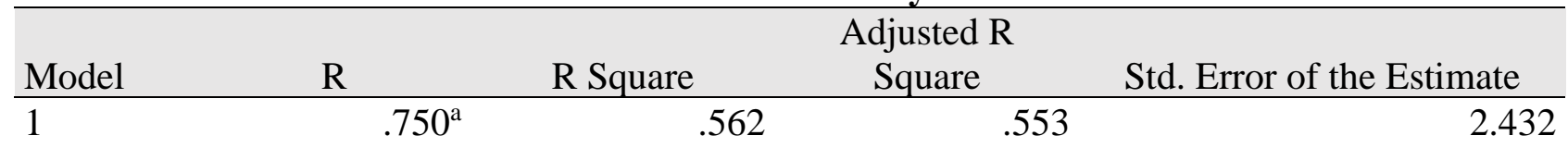

a. Predictors: (Constant), Kualitas pelayanan (X2), Harga produk (X1)

Berdasarkan hasil pengujian diperoleh nilai determinasi sebesar 0,562 artinya harga produk dan kualitas pelayanan secara simultan memiliki kontribusi pengaruh sebesar 56,2\% terhadap kepuasan pelanggan, sedangkan sisanya sebesar $43,8 \%$ dipengaruhi faktor lain.

\section{Uji Hipotesis}

\section{Uji hipotesis Parsial (Uji t)}

Pengujian hipotesis dengan uji t digunakan untuk mengetahui hipotesis parsial mana yang diterima. Hipotesis pertama: Terdapat pengaruh yang signifikan antara harga produk terhadap kepuasan pelanggan.

Tabel Hasil Uji Hipotesis Harga Produk Terhadap Kepuasan Pelanggan.

\section{Coefficients $^{\text {a }}$}

\begin{tabular}{|c|c|c|c|c|c|c|}
\hline \multirow{2}{*}{\multicolumn{2}{|c|}{ Model }} & \multicolumn{2}{|c|}{ Unstandardized Coefficients } & \multicolumn{2}{|l|}{ Standardized Coefficients } & \multirow[b]{2}{*}{ Sig. } \\
\hline & & B & Std. Error & Beta & $\mathrm{t}$ & \\
\hline 1 & (Constant) & 16.527 & 2.812 & & 5.877 & .000 \\
\hline & Harga produk (X1) & .589 & .073 & .635 & 8.061 & .000 \\
\hline
\end{tabular}

a. Dependent Variable: Kepuasan pelanggan (Y)

Berdasarkan hasil pengujian pada tabel di atas, diperoleh nilai t hitung $>\mathrm{t}$ tabel atau $(8,061>1,985)$, dengan demikian hipotesis pertama yang diajukan bahwa terdapat pengaruh yang signifikan atara harga produk terhadap kepuasan pelanggan diterima.

Tabel Hasil Uji Hipotesis Kualitas Pelayanan Terhadap Kepuasan Pelanggan.

\section{Coefficients $^{\mathrm{a}}$}

\begin{tabular}{|c|c|c|c|c|c|}
\hline \multirow[b]{2}{*}{ Model } & \multicolumn{2}{|c|}{$\begin{array}{c}\text { Unstandardized } \\
\text { Coefficients }\end{array}$} & \multirow{2}{*}{$\begin{array}{c}\text { Standardized } \\
\text { Coefficients } \\
\text { Beta }\end{array}$} & \multirow[b]{2}{*}{$\mathrm{t}$} & \multirow[b]{2}{*}{ Sig. } \\
\hline & B & Std. Error & & & \\
\hline 1 (Constant) & 13.064 & 2.627 & & 4.973 & .000 \\
\hline Kualitas pelayanan (X2) & .674 & .068 & .713 & 9.951 & .000 \\
\hline
\end{tabular}

a. Dependent Variable: Kepuasan pelanggan (Y)

Berdasarkan hasil pengujian pada tabel di atas, diperoleh nilai t hitung $>\mathrm{t}$ tabel atau $(9,951>1,985)$, dengan demikian hipotesis kedua yang diajukan bahwa terdapat pengaruh yang signifikan atara kualitas pelayanan terhadap kepuasan pelanggan diterima. 


\section{Uji Hipotesis Simultan (Uji F)}

Pengujian hipotesis dengan uji $\mathrm{F}$ digunakan untuk mengetahui hipotesis simultan yang mana yang diterima. Hipotesis ketiga Terdapat pengaruh yang signifikan antara harga produk dan kualitas pelayanan terhadap kepuasan pelanggan.

Tabel Hasil Uji Hipotesis Harga Produk dan Kualitas Pelayanan Terhadap Kepuasan Pelanggan.

\begin{tabular}{llrrrrr}
\multicolumn{8}{c}{ ANOVA $^{\mathbf{a}}$} \\
\hline Model & & Sum of Squares & \multicolumn{1}{c}{ df } & Mean Square & \multicolumn{1}{c}{ F } & \multicolumn{1}{c}{ Sig. } \\
\hline 1 & Regression & 721.290 & 2 & 360.645 & 60.957 & $.000^{\mathrm{b}}$ \\
& Residual & 562.057 & 95 & 5.916 & & \\
& Total & 1283.347 & 97 & & &
\end{tabular}

Berdasarkan hasil pengujian pada tabel di atas, diperoleh nilai $\mathrm{F}$ hitung $>\mathrm{F}$ tabel atau $(60,957>$ 2,770), dengan demikian hipotesis ketiga yang diajukan bahwa terdapat pengaruh yang signifikan atara harga produk dan kualitas pelayanan terhadap kepuasan pelanggan diterima.

\subsection{Pembahasan}

\section{Pengaruh Harga Produk Terhadap Kepuasan Pelanggan}

Harga produk berpengaruh signifikan terhadap kepuasan pelanggan dengan korelasi sebesar 0,635 atau memiliki hubungan yang kuat dengan kontribusi pengaruh sebesar $40,4 \%$. Pengujian hipotesis diperoleh nilai $t$ hitung $>t$ tabel atau $(8,061>1,985)$. Dengan demikian hipotesis pertama yang diajukan bahwa terdapat berpengaruh signifikan antara harga produk terhadap kepuasan pelanggan diterima.

\section{Pengaruh Kualitas Pelayanan Terhadap Kepuasan Pelanggan}

Kualitas pelayanan berpengaruh signifikan terhadap kepuasan pelanggan dengan korelasi sebesar 0,713 atau memiliki hubungan yang kuat dengan kontribusi pengaruh sebesar 50,8\%. Pengujian hipotesis diperoleh nilai thitung $>\mathrm{t}$ tabel atau $(9,951>1,985)$. Dengan demikian hipotesis kedua yang diajukan bahwa terdapat berpengaruh signifikan antara kualitas pelayanan terhadap kepuasan pelanggan diterima.

\section{Pengaruh Harga Produk dan Kualitas Pelayanan Terhadap Kepuasan Pelanggan}

Harga produk dan kualitas pelayanan berpengaruh signifikan terhadap kepuasan pelanggan dengan diperoleh persamaan regresi $\mathrm{Y}=9,390+0,281 \mathrm{X} 1+0,490 \mathrm{X} 2$, nilai korelasi sebesar 0,750 atau memiliki hubungan yang kuat dengan kontribusi pengaruh sebesar 56,2\% sedangkan sisanya sebesar 43,8\% dipengaruhi faktor lain. Pengujian hipotesis diperoleh nilai $\mathrm{F}$ hitung $>\mathrm{F}$ tabel atau $(60,957>2,770)$. Dengan demikian hipotesis ketiga yang diajukan bahwa terdapat berpengaruh signifikan antara harga produk dan kualitas pelayanan terhadap kepuasan pelanggan diterima.

\section{KESIMPULAN}

\subsection{Kesimpulan}

a. Harga produk berpengaruh signifikan terhadap kepuasan pelanggan dengan kontribusi pengaruh sebesar 40,4\%. Uji hipotesis diperoleh nilai t hitung $>\mathrm{t}$ tabel atau $(8,061>1,985)$.

b. Kualitas pelayanan berpengaruh signifikan terhadap kepuasan pelanggan dengan kontribusi pengaruh sebesar 50,8\%. Uji hipotesis diperoleh nilai $t$ hitung $>\mathrm{t}$ tabel atau $(9,951>1,985)$.

c. Harga produk dan kualitas pelayanan berpengaruh signifikan terhadap kepuasan pelanggan dengan kontribusi pengaruh sebesar 56,2\% sedangkan sisanya sebesar 43,8\% dipengaruhi faktor lain. Uji hipotesis diperoleh nilai F hitung > F tabel atau $(60,957>2,770)$.

\subsection{Saran}


a. Perusahaan harus mampu menerapkan harga produk yang bervariasi dan menyeimbangkan dengan tingkat kemampuan harga dipasaran

b. Perusahaan harus mampu memanfaatkan teknologi terkait dengan promosi agar dapat memberikan informasi kepada pelanggan secara cepat dan efektif.

c. Untuk meningkatkan kepuasan pelanggan, perusahaan harus secara kontinyu mangadakan survey pasar terkait dengan penentuan harga yang kompetitif serta meningkatkan pelayanan yang optimal.

\section{DAFTAR PUSTAKA}

Algifari. (2015). “Analisis Regresi untuk Bisnis dan Ekonomi”. Yogyakarta: BPFE.

Arikunto, Suharsimi (2014). “Prosedur Penelitian Suatu Pendekatan Praktek”. Jakarta: Rineka Cipta.

Griffin R.W., \& Ronald, J.E. (2003). Dasar-Dasar Pemasaran. Jakarta: Raja

Haudi, H. W., \& Cahyono, Y. (2020). Analysis of Most Influential Factors to Attract Foreign Direct Investment. Journal of Critical Reviews, 7(13), 4128-4135.

Kotler (2016) “Manajemen Pemasaran”. Edisi Keempat belas, Jakarta: PT. Indeks.

Lupiyadi, Rambat (2016) Manajemen Pemasaran Jasa edisi 2 , Jakarta : Salemba Empat.

Philip Kotler (2017) Manajemen Pemasaran, Edisi Keempat Belas, Jakarta: PT. Indeks.

Rao, Purba, (2012). “Measuring Consumer Perceptions Through Factor Analysis”, The Asian.

Santoso, Singgih (2015). “Menguasai Statistik Multivariat”. Jakarta: PT Elex Media Komputindo.

Sobarna, A., Hambali, S., Sutiswo, S., \& Sunarsi, D. (2020). The influence learning used ABC run exercise on the sprint capabilities. Jurnal Konseling dan Pendidikan, 8(2), 67-71.

Sudarsono, A., \& Sunarsi, D. (2020). Pengaruh Kualitas Pelayanan Dan Varian Produk Terhadap Keputusan Pembelian Pada Laboratorium Klinik Kimia Farma-Bintaro. Value: Jurnal Manajemen dan Akuntansi, 15(1), 16-26.

Sudjana (2014) “Metode Statistika”, Bandung: Tarsido.

Sugiyono (2017), "Metode Penelitian Administrasi : dilengkapi dengan Metode $R \& D$ ". Bandung: Alfabeta.

Suhartanto (2014). “Metode Riset Pemasaran”. Bandung: Alfabeta

Sunarsi, D. (2018). Pengembangan Sumber Daya Manusia Strategik \& Karakterisrik Sistem Pendukungnya : Sebuah Tinjauan. Jurnal Ilmiah MEA (Manajemen, Ekonomi, \& Akuntansi), 2(3), 178 - 194.

Sunarsi, D., \& Baharuddin, A. (2019). The Effect of Service Quality and Price Accuracy on Consumer Confidence and Implications for Sales Increase. PINISI Discretion Review, 3(2), 101 110.Ilmu Administrasi Publik, 9(2), 237-246.

Sunarsi, D., Wijoyo, H., Prasada, D., \& Andi, D. (2020, September). Pengaruh Lingkungan Kerja Terhadap Kinerja Karyawan pada PT. Mentari Persada di Jakarta. In Seminar Nasional Manajemen, Ekonomi, Akuntansi (Vol. 5, No. 1, pp. 117-123).

Sutrisno, S., \& Sunarsi, D. (2019). The Effect of Work Motivation and Discipline on Employee Productivity at PT. Anugerah Agung in Jakarta. Jurnal Ad'ministrare, 6(2), 187-196.

Wijoyo, H. (2018). Analisis Pengakuan Pendapatan dan Beban Kontrak Konstruksi Pada PT. Wahana Tata Riau. Jurnal Ilmu Komputer dan Bisnis, 9(2), 2034-2043. 